\title{
Katarzyna Byrska
}

\section{Nienawiść}

\section{w przestrzeni architektonicznej}

\section{Zawłaszczenie przestrzeni publicznej}

Istnieją różne aspekty wyrażania nienawiści w sposób inny niż fizyczny: poprzez słowa, pomówienia, szantaż emocjonalny, knowania etc. Nienawiść może się również przejawiać w sposób fizyczny, w różnych aspektach, poprzez akty przemocy fizycznej wobec innych osób lub przedmiotów nieożywionych, nienawistne obrazy. Uczucie to można również manifestować wizualnie, w przestrzeni oraz $\mathrm{w}$ jej zagospodarowaniu, w przedmiotach obecnych w przestrzeni publicznej, w architekturze poszczególnych budowli lub całych kompleksów budowlanych. Większość tych aktów złej woli lub agresji jest niezauważalna lub też tak wtopiła się w krajobraz, że przestaje być świadomie odczuwalna. Jednak zdarzają się miejsca, w których trudno czuć się komfortowo i bezpiecznie, odczuwa się w nich niepokój, bo miejsce to jest $\mathrm{w}$ pewien sposób naznaczone złymi intencjami. Prostym przykładem jest porównanie pięknie odnowionej zabytkowej starówki miasta i odległych od niej zarówno przestrzennie, jak i społecznie blokowisk. Jedno i drugie miejsce zostało wybudowane z myśla o użytkowaniu go przez ludzi, jednak panujący tam nastrój jest diametralnie różny, wręcz fizycznie odczuwalny. Jak pisze Piotr Winskowski: „Jakość życia zależy nie tylko od parametrów przestrzennych, ale też od umiejętności ich wykorzystania. Współdziałanie mieszkańców lub jego brak to proces społeczny, warunkowany przestrzenia, w której 
się odbywa"1. A zatem przestrzeń, w której mieszkamy, ma wpływ na charakter jej mieszkańców. Samo słowo "blokowisko”, użyte we współczesnym kontekście (np. ewokując paryskie banlieu), może wywoływać negatywne skojarzenia jako gęsto zaludniona, niezbyt estetyczna przestrzeń, pozbawiona rozrywek kulturalnych, gdzie poziom przestępczości jest znacznie wyższy niż w burżuazyjnej dzielnicy małych kamieniczek czy willi podmiejskich².

Współczesna otaczająca nas przestrzeń publiczna, w której istnieją elementy architektury (budynki mieszkalne, miejsca użyteczności publicznej, ale również tzw. mała architektura, tj. płotki, ławki, latarnie, kosze na śmieci, wiaty przystankowe etc.), a która z definicji powinna być dla wszystkich jednakowo dostępna, jest naznaczona różnymi przejawami nienawiści, złej woli, agresji uzewnętrznionej. To zjawisko obserwujemy zarówno w intensywnie zabudowanej przestrzeni miejskiej, jak i w mniej bogatej architektonicznie przestrzeni $\mathrm{w}$ terenach pozamiejskich. Ta wspólna przestrzeń zostaje zawłaszczona przez wszechobecne akty złej woli, nienawiści. Co więcej, mieszkańcy i przechodnie, czyli odbiorcy, użytkownicy przestrzeni stykający sie z taka zawłaszczona przestrzenia, nie pozostaja na nią obojętni. Chuligani czują się tam jak „u siebie”, przestrzeń została przez nich "oznaczona", objęta w posiadanie, inni natomiast czują się niepewnie. Wszystko to, co współcześnie otacza ludzi, a w szczególny sposób struktury urbanistyczne, "generuje i kanalizuje specyficzne oddziaływania przestrzenne. Kształt, faktura, kolor, gra świateł czy rytm ukryty w kompozycjach są silnymi bodźcami z całą swoją złożonościa i dynamiką oddziaływania. Interakcje zachodzące między żywym organizmem, jakim jest człowiek, a środowiskiem, jakim jest przestrzeń architektoniczna, kształtuja motywy określonych wyborów, oparte często na procesach afektywnych względem konkretnych bodźców płynących z tej przestrzeni"3. Jak to ujął skrótowo Allain de Botton: ,jesteśmy w niemiły sposób bezbronni wobec koloru tapety i nasze

${ }^{1}$ P. Winskowski, Miasto od przestrzeni do koncepcji przestrzeni i z powrotem, [w:] Miasto między przestrzenia a koncepcja przestrzeni, red. M. Banaszkiewicz, F. Czech, P. Winskowski, Kraków 2010, s. 13.

2 Pojęcie „dobrych i złych dzielnic" rozwijają B. Czarnecki, W. Siemiński, Kształtowanie bezpiecznej przestrzeni publicznej, Warszawa 2004, s. 52.

${ }^{3}$ A. Diec, Wzory preferencji przestrzeni architektonicznej, [w:] Miasto między przestrzenia a koncepcja przestrzeni, dz. cyt., s. 39. 
poczucie sensu może zostać zachwiane przez źle dobraną narzutę na łóżko"4. Przestrzeń architektoniczna staje się rodzajem nośnika, medium, wywołującego u ludzi „poczucie komfortu psychicznego i fizycznego, przeżycie jakiejś treści, wzruszenia, a nawet lęku"5.

\section{Nienawiść w przestrzeni publicznej}

Codziennie niemal na każdym kroku można zaobserwować ślady po działalności jakichś frustratów, którzy postanowili bezmyślnie wyładować swoją złość na koszu na śmieci, znaku drogowym, ławce, wiacie przystankowej etc. Obiekty małej architektury sa najbardziej bezbronnymi ofiarami wobec chuliganów, którzy niszcząc je, pokazuja światu swoją nienawiść. Nie chodzi im zazwyczaj o uczucie do tej konkretnej ławki czy płotku, ale raczej o ogólną niechęć do otaczającej rzeczywistości. Wyłamane deszczułki w ławkach, wywrócone kosze na śmieci, wybite szyby w wiacie przystankowej to nasza codzienność, obojętne, czy znajdują się w centrum miasta, czy na jego peryferiach lub też w pozornie spokojnej wiejskiej okolicy.

Kolejnym równie częstym przejawem pokazywania niechęci do świata są pojawiające się nagminnie napisy i graffiti na murach, parkanach, czasem chodnikach czy innych powierzchniach. W zależności od poziomu artystycznego ich twórców napisy te są najczęściej wulgarne lub nawet obsceniczne. $\mathrm{W}$ wielu przypadkach niosą również treści bezpośrednio nienawistne, skierowane do konkretnej grupy społecznej, etnicznej, konkurencyjnego klubu sportowego lub do konkretnej jednostki. Najczęściej pojawiające się odnośniki to epitety skierowane do narodu żydowskiego („anty jude”), do klubów piłkarskich („Cracovia pany”, „TS Wisła”) (il. 1). Przy okazji, posługując się wulgarnymi słowami, piszący może uzewnętrznić bardzo dosadnie swoje uczucia. Gdy nie wystarcza już agresja tylko słowna, niejako zastępczą ofiarą nienawiści padaja ściany budynków, parkany budów, wiaty przystankowe, bilboardy reklamowe, i to wcale niekoniecznie tylko w miejscach oddalonych od centrów życia i opuszczonych. Każda wolna powierzchnia jest potencjalnie zagrożona pseudoartystycznymi malowidłami, napisami lub obrazkami. Dzieła te pojawiają się

\footnotetext{
${ }^{4}$ A. de Botton, Architektura szczęścia, przekł. K. Środa, Kraków 2010, s. 24.

${ }^{5}$ M. Ostrowska, Człowiek a rzeczywistość przestrzenna, Szczecin 1991, s. 194.
} 
stale, mimo sprzeciwu społecznego oraz mimo ciagłego ich usuwania. Oczywiście istnieje cała gałąź sztuki ulicznej uprawiana w przeznaczonych do tego miejscach, o wysokim poziomie artystycznym, nie stanowi jednak przedmiotu rozważań w niniejszej pracy.

Wlepki to modne od niedawna naklejki, które w ramach rozmaitych akcji społecznych pojawiaja się w różnych miejscach. Można je spotkać w tramwajach, na przystankach, latarniach, słupach ogłoszeniowych, barierkach - wszędzie tam, gdzie pada wzrok przechodnia. Początkowo służące akcjom i kampaniom społecznym, szybko zostały przejęte przez nienawiść. Zamiast haseł społecznych, np. „zbieraj nakrętki", na wlepkach pojawiaja się obecnie napisy skierowane przeciwko czemuś lub komuś lub też mające drażnić (np. „Wisła rządzi”, „Kaczory precz” etc.). Ten rodzaj medium może też być bronią polityczną - wlepki pojawiaja się w odpowiedzi na decyzje władz lub przy okazji wyborów (,JJacek Majchrowski Kraków dziadowski”, il. 2). Przechodząc setki razy wobec tak „zanieczyszczonej” wizualnie przestrzeni, musimy poczuć się nieswojo. Taka przestrzeń publiczna, w której wizualnie pojawiaja się liczne przejawy wrogości, emanuje nienawiścią mimo jej świadomego ignorowania. Nasza podświadomość zostaje niejako zakażona nienawiścia, którą ktoś wcześniej w niej wyraził.

Powyższe przykłady to zawłaszczanie przestrzeni publicznej. Przestrzeń, która jest dostępna dla każdego, zostaje zanieczyszczona i zeszpecona. Jest nie tylko uzewnętrznionym wyrazem negatywnych uczućjego twórcy, ale wpływa również na samopoczucie przechodnia, który także doświadcza negatywnych uczuć - po pierwsze z powodu oszpecenia przestrzeni, czyli skazy estetycznej w przestrzeni architektonicznej, po drugie z powodu treści napisu. Jak podaje Agata Diec, „przestrzeń architektoniczna poprzez swoje nieustanne oddziaływanie wpływa na stany psychiczne człowieka, co - jak sugeruja wyniki badań - wpływa na podejmowanie konkretnych działań i zachowanie ludzi w tych przestrzeniach przebywających" ${ }^{\prime \prime}$. U osoby agresywnej zetknięcie się z takimi przejawami agresji spowoduje jej wzmocnienie i kumulację, co może za soba pociagnać dalsze akty nienawiści. Bartosz Czarnecki i Waldemar Siemiński opisuja te zjawiska (wandalizm, niszczenie infrastruktury miejskiej, graffiti i nielegalne plakatowanie) jako zanieczyszczenie przestrzeni

\footnotetext{
${ }^{6}$ A. Diec, Wzory preferencji przestrzeni architektonicznej, dz. cyt., s. 54.
} 
Ilustracja 1.

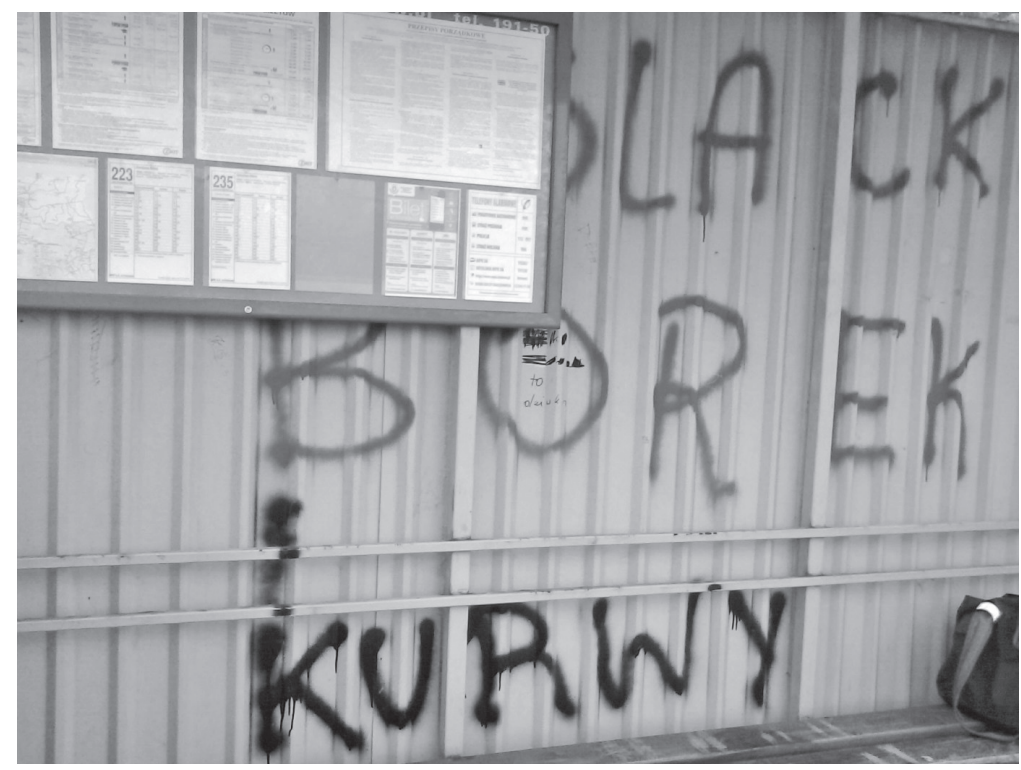

Ilustracja 2.

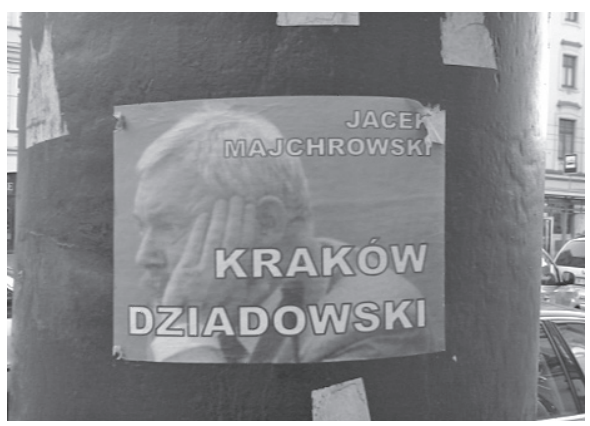


publicznej porównywalne z nieuprzątniętymi śmieciami ${ }^{7}$. Według nich przestrzeń bez widocznego nadzoru, a taka jest przestrzeń zawłaszczona przez akty złej woli, wywołuje poczucie zagrożenia. Zjawiska wizualnego zanieczyszczenia przestrzeni powoduja daleko idace skutki ekonomiczne i społeczne oraz osłabiają autorytet władz administracyjnych ${ }^{8}$.

\section{Nienawiść a przestrzeń wirtualna}

Obecnie przestrzeń publiczna to nie tylko przestrzeń fizyczna. Ponieważ wiele aspektów życia przeniosło się do przestrzeni wirtualnej, tam również nienawiść przejawia się na wiele sposobów. Na najpopularniejszym portalu społecznościowym można bez trudu znaleźć strony otwarcie i bez ograniczeń nawołujące do wyrażania nienawiści. Nie będzie tu jednak rozważane powstawanie domen neonazistowskich ani też tworzenie się organizacji terrorystycznych, interesujące są przejawy nienawiści w przestrzeni architektonicznej.

Na Facebooku powstaja licznie strony w podobnym stylu, jak np. Nie jestem z Warszawy! (ponad 25 tys. kliknięć "Lubię to" ${ }^{\prime \prime}$ ), Jestem z Krakowa, nie lubię Warszawy (prawie 11 tys. osób wyraziło poparcie ${ }^{10}$ ), które w rekordowym czasie zyskują na popularności. Na ich forum tymczasowi mieszkańcy stolicy wyrażają niechęć do miejsca, w którym przyszło im mieszkać, ale większość wpisów jest umieszczonych przez osoby spoza Warszawy, które nie lubią tego miasta bez żadnej konkretnej przyczyny („,źle się czuję w Warszawie"11 wpis z forum z 26.10.2011). O ile jesteśmy w stanie zrozumieć stałych mieszkańców, którzy widzą braki i niedogodności miasta, o tyle niechęć wyrażana przez osoby spoza Warszawy jest zupełnie nieuzasadniona. Wiele wpisów to komentarze o sytuacji, na którą mieszkańcy nie mają żadnego wpływu: „Starówkę mamy lepsza, zamek niedawno odbudowany, przynajmniej

7 B. Czarnecki, W. Siemiński, Kształtowanie bezpiecznej przestrzeni publicznej, dz. cyt., s. 58-59.

8 Tamże.

${ }_{9}$ Nie jestem $z$ Warszawy, https://www.facebook.com/niejestemzwarszawy (15.02.2015).

${ }_{10}$ Jestem z Krakowa nie lubię Warszawy, https://www.facebook.com/pages/Jestem-z-Krakowa-nie-lubi\%C4\%99-Warszawy/309067672442837 (15.02.2015).

${ }_{11}$ Jestem z Krakowa nie lubię Warszawy, https://www.facebook.com/pages/Jestem-z-Krakowa-nie-lubi\%C4\%99-Warszawy/309067672442837 (15.02.2015). 
jest metro"12 (wpisy z forum z 15.05 - 15.11.2014). To przejawy czystej niechęci wobec struktur wizualnych, przestrzeni architektonicznej miasta. Nieco chaotyczna zabudowa szybko rozwijającej się przestrzennie Warszawy to również przestrzeń zawłaszczona, zabrana odbiorcom i pozbawiona harmonii. To powoduje niechęć do miasta i automatycznie przekłada się na nastawienie do jej mieszkańców.

\section{Nienawiść w budownictwie}

Aktem złej woli jest również budowanie komuś na złość. Właściciel parceli, aby dokuczyć sąsiadowi, buduje swój dom tuż na wprost okien innego domu ${ }^{13}$. Wprawdzie zgodnie z przepisami prawa, ale niezgodnie $\mathrm{z}$ dobrosasiedzkimi stosunkami. Budynek postawiony zbyt blisko odcina sąsiadom dopływ światła, a ponadto obie strony narażone są na zaglądanie sobie wzajemnie w okna i naruszanie prywatności. W wielu wypadkach jest to tylko wyraz złej woli (złośliwości) konstruktora budynku lub zleceniodawcy prac. Innymi przykładami sa różnego rodzaju mury czy inne podziały sztucznie dzielące zwarte architektonicznie struktury. Wiele budowli jest wzniesionych w oparciu o zamierzenia, które w efekcie wywołują uczucie niepokoju, brak poczucia komfortu u patrzącego. Przykłady narożnych szpiczastych budowli, skomplikowanych założeń konstrukcyjnych brył kościołów czy innych budynków użyteczności publicznej z niewłaściwie z punktu widzenia odbiorcy rozwiązanymi kwestiami oświetlenia (światło zbyt rozproszone, niewystarczające) czy wejść i wyjść (za wąskie, niewystarczająca liczba wobec pojemności sal), niezbyt trafnie wstawionych, rażąco odcinających się na tle innych budynków tzw. plomb w ciaggu zabytkowych fasad, można mnożyć. Struktury takie wzbudzaja niechęć $\mathrm{i}$ dyskomfort $\mathrm{w}$ przechodniach, pozostawanie przez dłuższy czas wewnątrz takiej „błędnej” konstrukcji wywołuje negatywny nastrój. Konstrukcje te sa z pewnością doskonale wyliczone i zaprojektowane pod względem technicznym, jednak oprócz funkcji stricte użytecznej liczy się również wkład w ogólną harmonię przestrzenną. Według

${ }_{12}$ Jestem z Krakowa nie lubię Warszawy, https://www.facebook.com/pages/Jestem-z-Krakowa-nie-lubi\%C4\%99-Warszawy/309067672442837 (15.02.2015).

${ }^{13}$ Np. tzw. „Dom złości” w Bejrucie, por. T. E. Hall, Ukryty wymiar, przeł. T. Hołówka, Warszawa, 2001, s. 205 oraz ilustracja 22. 
Karla Friedricha Schinkela „obowiązkiem architektury jest uczynienie rzeczy użytecznej, praktycznej i funkcjonalnej czymś pięknym"14.

Szczególnym przypadkiem wpływu architektury na nastrój są osiedla bloków z tzw. wielkiej płyty. Wybudowane w wielu miejscach na świecie $w$ okresie powojennego boomu demograficznego sa użyteczne, praktyczne i funkcjonalne, zapewniaja schronienie i dach nad głową milionom mieszkańców. Jak argumentuje Edward Twitchell Hall, istnieje zdecydowana różnica między mieszkaniem w slumsach a mieszkaniem w blokach, które je zastapiły, jednak w blokach nie mieszka się dobrze ${ }^{15}$. Problem polega nie tylko na zgromadzeniu na niewielkiej przestrzeni dużej liczby mieszkańców, ale również na zaniedbaniu tego ostatniego obowiązku architektury - zapewnienia piękna. Mimo starań władz komunalnych o więcej przestrzeni zielonej i innych udogodnień dla mieszkańców (parkingów, sklepów, przedszkoli, placów zabaw, estetyki małej architektury etc.) o blokowiskach raczej nikt nie powie, że sa piękne. Przebywając w nieładnym otoczeniu, mieszkańcy nieświadomie nabierają niechęci do tego miejsca. Stłoczenie wielu ludzi na niewielkiej powierzchni powoduje agresję, a ta przekłada się z kolei na działania opisane powyżej, uzewnętrznianie agresji. Jak argumentuja Bartosz Czarnecki i Waldemar Siemiński, „agresja mieszkańców blokowisk wobec miejsca zamieszkania to w dużej mierze przejaw braku utożsamienia z miejscem i braku więzi sąsiedzkich"16. W przestrzeni, gdzie mieszka zbyt dużo ludzi i gdzie aspekt estetyczny został niemal całkowicie pominięty na korzyść aspektów praktyczno-funkcjonalnych, mieszka się źle ${ }^{17}$. To odwrotność tezy Alana de Bottona, który twierdzi, że „harmonijny dom jest obietnicą harmonijnego życia"18. To kolejny przykład zawłaszczonej

${ }^{14}$ A. de Botton, Architektura szczęścia, dz. cyt., s. 46. Należy tu rozróżnić znaczenie pojęć „,użyteczny” jako „przynoszący pożytek, potrzebny do czegoś”; , praktyczny” jako ",oparty na praktyce”, ale i „przeznaczony do zastosowania w praktyce”; ,,funkcjonalny" jako „dobrze spełniający swoją funkcję"; definicje wg Słownika języka polskiego PWN, sjp.pwn.pl (01.07.2015).

${ }^{15}$ E. T. Hall, Ukryty wymiar, dz. cyt., s. 214.

16 B. Czarnecki, W. Siemiński, Kształtowanie bezpiecznej przestrzeni publicznej, dz. cyt., s. 57.

17 E. T. Hall, Ukryty wymiar, dz. cyt., s. 214, zob. także B. Czarnecki, W. Siemiński, Ksztattowanie bezpiecznej przestrzeni publicznej, dz. cyt., s. 21-22.

${ }_{18}$ A. de Botton, Architektura szczęścia, dz. cyt, s. 199. 
przestrzeni, która nie spełnia powierzonych jej zadań budowania przestrzeni społecznej ${ }^{19}$.

\section{Aspekt estetyczny budownictwa}

Przestrzeń ma istotny wpływ na przebywających w niej ludzi. Szczególne znaczenie ma przestrzeń miejska, która jest wytworzona przez deweloperów, władze miasta, spółdzielnie zarządzające domami, właścicieli posesji i w końcu mieszkańców. Zła organizacja przestrzeni hamuje rozwój społeczny - nazywa się ja „ułomna”, ,"zdeformowana”" ${ }^{20}$. Samopoczucie człowieka jest podświadomie uzależnione od otoczenia, w którym przebywa, jest to tak zwane społeczne wytwarzanie przestrze$\mathrm{ni}^{21}$. Jak twierdzi de Botton: „Architektura, nawet w swoich najdoskonalszych formach, zawsze będzie słabym i niedoskonałym (kosztownym, podatnym na zniszczenie i moralnie zawodnym) protestem przeciwko stanowi rzeczy" ${ }^{\prime 22}$. Architektura jest wyrazem idei danego czasu. W opinii psychologów „dzisiejsze osiedla nie spełniają żadnych standardów ani nie pełnia żadnych funkcji społecznych. Tworzy się zdehumanizowane przestrzenie o zdegradowanych funkcjach przestrzennych" ${ }^{23}$, jak podsumował Zbigniew Nęcki, juror konkursu Archi-Szopa.

Jedną z form protestu przeciwko postępującemu procesowi zawłaszczania przestrzeni architektonicznej, a właściwie piętnowania tego „zdeformowania” organizacji przestrzennej oraz po prostu brzydoty, jest konkurs Archi-Szopa. W corocznym plebiscycie organizowanym przez redakcję „Gazety Wyborczej” w Krakowie każdy czytelnik może wskazać swojego kandydata na najgorszą (najbrzydszą, niefunkcjonalną lub po prostu niepasujaca do otoczenia, w jakim została umieszczona) budowlę powstałą $\mathrm{w}$ ciagu ostatniego roku. Na forum toczą się dyskusje o właściwym zagospodarowaniu przestrzeni oddanej pod zabudowę danego obiektu, wśród nich powtarzają się opinie, że dany

19 Zob. A. Majer, Socjologia i przestrzeń miejska, Warszawa 2010, s. 69.

${ }_{20}$ Zob. M. Malikowski, S. Solecki, Społeczeństwo i przestrzeń zurbanizowana. Teksty źródłowe, wyd. 2, Rzeszów 2011.

${ }_{21}$ Zob. A. Majer, Socjologia i przestrzeń miejska, dz. cyt., s. 69.

22 A. de Botton, Architektura szczęścia, dz. cyt., s. 24.

23 D. Hajok, M. Żurawik, Ruczaj i Kuźnica - Archi-Szopa 2012 za stracone szanse, http://krakow.gazeta.pl/krakow/1,44425,13475033,Ruczaj_i_Kuznica___Archi_Szopa_ 2012_za_stracone_szanse.html (11.02.2015). 
budynek nie tylko nie wpisuje się w kontekst, ale wręcz przeszkadza lub drażni, a nawet wzbudza agresję przechodzących - odbiorców tej architektury. W ten sposób opinię „, arogancji wobec dostojnego otoczenia" zdobył Ołtarz Trzeciego Tysiąclecia na Skałce (Archi-Szopa w roku $2008)^{24}$, a pomnik Piotra Skargi na placu Marii Magdaleny „niszczy przestrzeń architektoniczną i zasłania widok na ważne i piękne budynki” (Archi-Szopa w roku 2001) ${ }^{25}$. Natomiast osiedle Kuźnica Kołłątajowska oraz osiedle Ruczaj zdobyły ten niechlubny tytuł jako „,niesamowita platanina bezhołowia urbanistycznego i stracone szanse Krakowa na stworzenie spójnej tkanki miejskiej, przy sprzyjającym ruchu inwestorskim i posiadanych funduszach" (Archi-Szopa w roku 2012) ${ }^{26}$. To właśnie ta arogancja budowli wobec odbiorców prowadzi do opisanych wcześniej prób uwolnienia napięcia poprzez wizualne akty agresji wobec „,ułomnej" przestrzeni wspólnej. Zależności między poszczególnymi elementami w przestrzeni moga „umożliwiać dobre warunki funkcjonowania lub przyczyniać się do potęgowania konfliktów i agresji”27.

\section{Jażem to budował nie tobie, ty też buduj kwoli sobie}

Wszystkie opisane powyżej przykłady zawłaszczenia przestrzeni są całkowicie współczesne. Jednak zadaniem architektury od jej początków było tworzenie przestrzeni w stylu będącym uosobieniem ducha danej epoki. Każdy architekt miał ambicje postawić sobie pomnik z kamienia, który po latach przy pomni jego nazwisko. Nie jest również nowe zjawisko wyrażania budowlą złej woli, jak również zjawisko wyrażania niechęci wobec jakiejś budowli. Dom krakowskiego architekta Władysława Ekielskiego u zbiegu dzisiejszej ulicy Piłsudskiego i al. Mickiewicza w Krakowie, w chwili powstania spotkał się z ogromną krytyką współczesnych, dość dosadnie manifestujących sprzeciw dla idei sztuki eklektyzmu i rodzącej się secesji. Pisano między innymi: „Tymczasem ulica Wolska jest ściekiem poronionych płodów architektury, a potworek wyległy u jej wylotu (ostatni dom po lewej stronie) mało ma

24 Archi-Szopa. Zobacz poprzednich laureatów, http://krakow.gazeta.pl/krakow/ 56,35798,10551251,2008__Oltarz_na_Skalce,8.html (10.02.2015).

${ }_{25}$ Archi-Szopa. Zobacz poprzednich laureatów, dz. cyt.

${ }^{26}$ D. Hajok, M. Żurawik, Ruczaj i Kuźnica-Archi-Szopa 2012 za stracone szanse, dz. cyt.

27 B. Czarnecki, W. Siemiński, Kształtowanie bezpiecznej przestrzeni publicznej, dz. cyt., s. 22 . 
równych sobie nawet w Krakowie okazów. Ta baszta jak cylinder, nie wiadomo, czy służy za rezerwuar na wodę kolei obwodowej, z która się styka, czy jest to kocioł „,wielkiej pralni hygienicznej”, czy też „prywatne crematorium" ${ }^{\prime 28}$. Wobec tak miażdżącej krytyki Ekielski uznał za stosowne umieścić na fasadzie wspomnianego budynku inskrypcję o treści: „Jażem to budował nie tobie, ty też buduj k'woli sobie”29.

Dzisiaj natomiast zarówno budynek narożny, jak i cała ulica „poronionych płodów" jest uważana za perłę architektury, a fasady krakowskich kamienic przy dawnej ulicy Wolskiej, w większości przywrócone do stanu pierwotnej świetności, są wzorem kunsztu pod względem konstrukcji i zdobnictwa dla współczesnych projektantów. Dzisiaj nikt nie uznaje domu własnego Ekielskiego za potworka, a zabudowy tej ulicy za nieestetyczną czy też wzbudzającą agresję lub nienawiść. Wśród współczesnych „tworów, plątaniny bezhołowia urbanistycznego i zdehumanizowanej przestrzeni społecznej o zdegradowanych funkcjach" architektura sprzed wieku wydaje się ostoją harmonii i piękna. A może jednak współczesne konstrukcje również mają szansę przetrwać próbę czasu? Gust odbiorców architektury się zmienia, zgodnie z aktualnie obowiązującymi trendami. Niezmienne sajednak mechanizmy odbioru społecznego, według których przestrzenie niezadbane postrzegane sa jako pozbawione nadzoru lub niczyje; przebywanie w nich wzbudza poczucie braku bezpieczeństwa i wywołuje negatywne emocje ${ }^{30}$. Architekci i urbaniści odpowiedzialni za kształtowanie przestrzeni publicznej, podobnie jak architekci secesyjni, powinni szukać ,,stylu nowego, ale harmonijnego i zarazem funkcjonalnego, tworząc dzieła sztuki totalnej, który pozwoli na połączenie struktury i zdobnictwa, sztuki i życia codziennego" ${ }^{31}$. Zależność pomiędzy przestrzenią wizualną a jej wpływem na kształtowanie zachowań społecznych jej odbiorców jest niezwykle istotna. Otaczająca przestrzeń nie powinna prowokować do wyrażania nienawiści ani jej wzmacniać. Przestrzeń architektoniczna traktowana jako dobro wspólne, nie powinna też być zawłaszczana przez jakąś grupę społeczna, bez różnicy czy będą to kibice - wandale, czy architekci o miernych zdolnościach.

28 Zob. F. Chwalibóg, Brzydki Kraków, Kraków 1908, s. 14, cyt. za: J. Purchla, Jak powstał nowoczesny Kraków, Kraków 1990, s. 73.

${ }^{29}$ Napis znajdował się na belkowaniu loggi pierwszego piętra, dziś juz nie zachowany. Zob. J. Purchla, dz. cyt., s. 73.

${ }^{30}$ B. Czarnecki, W. Siemiński, dz. cyt., s. 58.

${ }^{31}$ Zob. H. Barton, N. Valbousquet, V. Vermeil, Paris Art Nouveau, Paryż 2008, s. 5. 


\section{Słowa kluczowe}

przestrzeń architektoniczna, przestrzeń społeczna, wizualne przejawy nienawiści

\section{Summary}

The article is treating the question of the visual representations of the hate in the architectural space. It tries to approach the issue of the hate in its socio-architectural aspects. There are shown different examples of hate's representation in the everyday space, like graffitis, stickers, net groups or competitions showing the ugliness of some building or constructions, vandalism or "wrong", dysfunctional architecture of the whole entities, as in the case of districts of block of flats. The article is shortly but clearly emphasizing the role and the impact of the architectural structures on the human behavior and feelings. The author is calling this phenomenon as appropriating of the public space, whereas the feeling of the hate dominates the neighbourhood and influences people who live there or are just passing by. The author though remarks that the architectural space should be treated as a common wealth, as it has a strong impact on the whole community.

\section{Keywords}

architectural space, social space, visual manifestations of hatred

\section{Bibliografia}

Banaszkiewicz M., Czech F., Winskowski P., Miasto między przestrzeniq a koncepcja przestrzeni, Kraków 2010.

Barton H., Valbousquet N., Vermeil V., Paris Art Nouveau, Paris 2008.

Czarnecki B., Siemiński W., Kształtowanie bezpiecznej przestrzeni publicznej, Warszawa 2004.

De Botton A., Architektura szczęścia, przekł. K. Środa, Kraków 2010.

Frysztacki K., Miasta metropolitarne i ich przedmieścia. Z problematyki socjologii miasta oraz badań nad rzeczywistością krakowska, Kraków 1997.

Hall E. T., Ukryty wymiar, przeł. T. Hołówka, Warszawa 2001.

Majer A., Socjologia i przestrzeń miejska, Warszawa 2010.

Ostrowska M., Człowiek a rzeczywistość przestrzenna, Szczecin 1991.

Purchla J., Jak powstał nowoczesny Kraków, Kraków 1990.

http://krakow.gazeta.pl/krakow/ (28.10.2014). 